\title{
How Much I Am Aware of Human Papilloma Virus (HPV)?
}

\author{
Human Papilloma Virüsün (HPV) Ne Kadar Farkındayım?
}

\author{
Derya Kaya Şenol*
}

\begin{abstract}
Objective: Cervical cancer which is the third leading cancer among females worldwide is one of the most common cancers with poor prognosis among females particularly in developing countries. This study was carried out as a descriptive study with the aim of determining the knowledge, attitudes and opinions of women about cervical cancer and HPV vaccine. Methods: The study was conducted with 186 women who applied to Gynecology and Obstetrics Clinic of Cankiri State Hospital due to gynecological reasons, who had not been previously diagnosed with cancer and who agreed for participation between October and December 2018. Data collection form included questions about the women's demographic, obstetric and gynecological histories, knowledge and attitudes toward cervical cancer and HPV vaccine. Results: Of the women included in the study, $41.4 \%$ were between ages 35 and 50, 52.2\% were graduates of elementary school, $96.8 \%$ had social security and $74.7 \%$ were housewives. $48.9 \%$ of the women were detected to have knowledge about cervical cancer and the best-known protection method against cervical cancer (36.6\%) was detected to be regular vaginal examination / pap-smear test. $16.1 \%$ of the women stated that they had heard of Human papilloma virus (HPV), of them, 80\% (n:24 knew that HPV causes cervical cancer. Almost all women (93.0\%) reported that they did not accept HPV vaccination for their daughters. The rate of being aware of cervical cancer, prevention methods, early diagnosis tests increased as the education level of women increased, and being volunteer for cervical smear sampling for screening purpose was found to be higher among women graduates of elementary school and above 35 years $(p<0.05)$. Conclusion: Educations should be planned in order to increase the awareness of women about cancer prevention and HPV vaccine by taking the age and educational status of women into consideration.
\end{abstract}

Key words: Human papilloma virus(HPV), HPV vaccine, cervical cancer, awareness

\section{ÖZET}

Amaç: Dünyada kadın kanserleri arasında üçüncü sırada yer alan serviks kanseri; özellikle gelişmekte olan ülkelerde, kadınlarda en sık görülen ve prognozu kötü seyreden kanserlerden biridir. Bu çalışma kadınların rahim ağzı kanseri ve HPV aşısı hakkında bilgi, tutum ve görüşlerini belirlemek amacıyla tanımlayıcı olarak yapıldı. Yöntem: Araştırma Ekim -Aralık 2018 tarihleri arasında Çankırı Devlet Hastanesi Kadın Hastalıkları ve Doğum polikliniğine jinekolojik nedenlerle başvuran, daha önce kanser tanısı almayan ve araştırmayı kabul eden 186 kadınla yürütüldü. Veri toplama formu; kadınların demografik, obstetrik, jinekolojik öyküleri ile rahim ağzı kanseri ve HPV aşısına yönelik bilgi ve tutumlarını belirlemeye yönelik sorulardan oluşmaktadır. Bulgular: Araştırma kapsamına alınan kadınların \%41,4'ünün 35-50 yaş aralığında olduğu, \%52,2'sinin ilköğretim mezunu, \%96,8'inin sosyal güvencesinin olduğu ve \%74,7'sinin ev hanımı olduğu belirlendi. Kadınların \%48,9'unun rahim ağzı kanseri hakkında bilgi sahibi olduğu ve rahim ağzı kanserinden korunmada en yüksek oranda (\%36,6) bilinen yöntemin düzenli vaginal muayene/pap-smear testi olduğu saptandı. Kadınların \%16,1'i Human papilloma virüsünü (HPV) duyduklarını ifade ettiler. Human papilloma virüsünü (HPV) duyduklarını ifade eden kadınları \%80'i (24 kadın) HPV'nin rahim ağzı kanserine neden olduğunu bilmekteydi. Kadınları tamamına yakını $(\% 93,0)$ kızlarına HPV aşısı yaptırmayı kabul etmediğini belirtti. Kadınların eğitim seviyesi arttıkça rahim ağzı kanseri, korunma yolları, erken tanı sağlayan testleri bilme oranlarının arttığı, tarama için örnek aldırma davranışlarının ilköğretim mezunu ve 35 yaş üstü kadınlarda daha yüksek olduğu(p<0.05) saptandı. Sonuç: Kadınların kanserden korunma ve HPV aşısı konusunda farkındalığının artması ile davranış değişikliği oluşması için kadınların yaş ve eğitim durumları göz önünde bulundurularak eğitimler planlanmalıdır.

Anahtar kelimeler: Human papilloma virüs (HPV), HPV aşısı, rahim ağzı kanseri, farkındalık

Received / Geliş tarihi: 07.03.2019, Accepted / Kabul tarihi: 05.07.2019

Department of Midwifery, Faculty of Health Sciences, Osmaniye Korkut Ata University, Osmaniye, Turkey

*Address for Correspondence / Yazışma Adresi: Derya Kaya Şenol, Department of Midwifery, Faculty of Health Sciences, Osmaniye Korkut Ata University, Osmaniye, Turkey, E-mail:dderya kaya@hotmail.com

Şenol DK. İnsan Papilloma Virüsün (HPV) ne kadar farkındayım? TJFMPC, 2019;13 (4): 462-471.

DOI: $10.21763 /$ tjfmpc. 651359 


\section{Gİiș}

Dünyada kadın kanserleri arasında 3. sırada yer alan serviks kanseri özellikle gelişmekte olan ülkelerde kadınlarda en sık görülen ve prognozu kötü seyreden kanserlerden biridir. ${ }^{1}$ Güneydoğu Asya, Latin Amerika ve Sahra altı Afrika gibi az gelişmiş ülkelerde Human PapillomaVirus'e (HPV) bağlı hastalık yükü ve rahim ağzı kanserinin yüksek olması en önemli halk sağlığ sorunlarından biri olarak belgelendirilmektedir. ${ }^{2,3,4}$ Ülkemizde ise serviks kanseri, tüm yaş grubu kadınlarda görülen kanserler arasında 9. sırada yer alırken, 25-49 yaş grubundaki kadınlarda en sik görülen 5 . kanserdir. ${ }^{5}$ Birden fazla cinsel partner, cinsel aktivitenin erken yaşta başlaması, paritenin artması, erken yaşta evlilik ve çocuk doğurma, kötü kişisel hijyen, düşük sosyo-ekonomik durum, 5 y1l veya daha uzun süre boyunca hormonal kontraseptif kullanımı, mevcut veya önceden cinsel yolla bulaşan enfeksiyon ve sigara içmek rahim ağzı kanseri için risk faktörleridir., ${ }^{6,7}$ Cinsel yolla bulaşan yaygın bir enfeksiyon olan insan papilloma virüsü (HPV), rahim ağzı kanserinin birincil nedenidir. ${ }^{8}$ Insan papilloma virüsü (HPV) serviks, vulva, vajina, penis, anüs ve orofarenkste kalıcı infeksiyon ve kansere neden olmaktadır. ${ }^{1} \mathrm{HPV}$, servikal kanserle ilişkisi kesin olarak saptanmış Parvovirus ailesinden, çift sarmallı, zarfsız bir DNA virüsüdür. Tanımlanmış 200'den fazla tipi olmakla birlikte HPV tip 16 ve 18 kanserlerin yaklaşık \% 7080 'ninden sorumlu tutulmaktadır. ${ }^{2,9}$

HPV ve serviks kanseri arasındaki bağlant,, araştırmacıları serviks kanseriniönleyici etkin bir aşının bulunması üzerine yoğunlaştırmıştır. HPV aşısı konak hücreleri infekte etmeden, HPV'yi nötralize eden humoral antikorları açığa çıkarmaktadır. ${ }^{10}$ Amerika Birleşik Devletleri Gıda ve İlaç İdaresi (FDA) tarafından 2006 yılında onaylanan HPV aşısı, rahim ağzı kanserinin primer önlenmesi için en büyük firsatı sunmaktadır. ${ }^{11}$ Kuadrivalen ( tip 6, 11, 16 ve 18'e etkili) ve Bivalen (tip 16 ve 18 'e karşı etkili) olmak üzere iki formu bulunan HPV aşısının 9-15 yaş aralığındaki kız çocuklarına uygulanması önerilmektedir. Her iki HPV aşısının altı aylık zaman diliminde $3 \mathrm{doz}$ şeklinde uygulanması tavsiye edilmektedir. ${ }^{12}$ Dünya Sağlık Örgütü'ne (WHO) göre, HPV'ye karşı aşılama, rahim ağzı kanserinin önlenmesinde temel bir stratejidir. ${ }^{13}$

Servikal kanser tarama programları rahim ağzı kanserlerinin erken evrede tanılanması ve ölüm oranlarını azaltmak için son derece önemli olmasına rağmen ${ }^{9}$ tarama programlarının eksikliği, sağlık bakımına sınırlı erişim, belirli davranışsal faktörleri etkileyen kültürel değerler, sosyal çevre ve inançlar dünyanın farklı bölgelerinde yaşayan kadınlarda prevalansı etkilemektedir. ${ }^{1}$ Gelişmiş ülkelerde kadınların \% 85'i yaşamlarında en az bir kez Pap smear testi yaparken, az gelişmiş ülkelerde bu oran sadece \% 5'tir. Kadınlarda rahim ağzı kanseri taramasının cinsel aktiviteye başlamasından üç yıl sonra yapılması önerilmektedir. ABD'de 21 yaşında ve Avrupa'da 25 yaşında başlaması tavsiye edilmektedir. Türkiye'de Ulusal Rahim Ağzı Kanseri Taraması Standartları, 30 ila 65 yaşları arasında her beş yılda bir tekrarlayan taramalar yapılmasını, son iki HPV veya Pap-smear testi negatif olan 65 yaşındaki kadınlarda taramanın kesilmesi önerilmektedir. ${ }^{14,15}$ Rahim ağZı kanserinin primer önlenmesi, HPV infeksiyonunun önlenmesi yoluyla gerçekleştirilir. Riskli cinsel aktiviteden uzak durma, tek eşlilik veya \%100 koruma sağlayan kondom kullanımı, tarama programları ve HPV aşılama farkındalığının artırılması HPV infeksiyonunu önlemede esastır. ${ }^{16} \mathrm{Bu}$ çalışma kadınların rahim ağzı kanseri ve HPV aşısı hakkındaki bilgi, tutum ve görüşlerini belirlemek amacıyla yapıldı.

\section{GEREÇ VE YÖNTEM}

Araştırmanın Evreni ve Örneklemi: Tanımlayıcı tipte olan araştırmanın evrenini Şubat-Nisan 2019 tarihleri arasında Çankırı Devlet Hastanesi Kadın Hastalıkları ve Doğum polikliniğine jinekolojik nedenlerle başvuran kadınlar oluşturdu. Örnekleme araştırmanın planlandığı tarih aralığında, jinekolojik nedenlerle polikliniğine başvuran, araştırmaya katılmayı kabul eden ve daha önce rahim ağzı kanseri tanısı almayan186 kadın dahil edildi. Veriler araştırmacı tarafindan literatür taranarak oluşturulmuş veri toplama formu ile toplandı. Anket sorularının anlaşılabilirliğini saptamak için önce 30 kadına uygulandı. Pilot aşamada sorularla ilgili herhangi bir sorun bildirilmediği için anket olduğu şekilde kullanıldı. Veri toplama formu; kadınların demografik, obstetrik, jinekolojik öyküleri ile rahim ağzı kanseri ve HPV aşısına yönelik bilgi ve tutumlarını belirlemeye yönelik olup toplam 32 sorudan oluşmaktadır. Kadınlar çalışma hakkında bilgilendirildikten sonra çalışmayı kabul edenlere anket formunda bulunan sorular soruldu ve veriler araştırmacı tarafından toplandı.

Araştırmanın Etik Yönü: Araştırmaya başlamadan önce çalışma amaç, yöntem ve veri toplama araçlarını içeren bir rapor, Çankırı Karatekin Üniversitesi Etik Kurulu'na sunuldu (Karar No:2018/53. Tarih: 12.10.2018). Etik kurul onay1 alındıktan sonra araştırmanın yapılacağı Çankırı Devlet Hastanesi'nden yazılı izin alındı. Elde edilen araştırma verilerinin, katılımcıların isimlerini kullanmadan bilimsel amaçlı olarak kullanılacağı ve yayınlanacağı bireylere açıklandı ve Helsinki Bildirgesi'ne uygun olarak sözlü onam alındı.

Verilerin Değerlendirilmesi: İstatistiki analizler SPSS paket programında yapıldi. İstatistik anlamlılık olarak $\mathrm{p}<0.05$ alınd. Tanımlayıcı istatistikler (frekans, yüzdeler, ortalamalar ve 
standart sapmalar) örneklemde ana değişkenleri tanımlamak için kullanıldı. Kadınların bazı özelliklerine göre rahim ağzı kanser bilgi düzeyleri ve farkındalıklarını karşılaştırmak için Ki-kare testi kullanıldı.

\section{BULGULAR}

Araştırmaya alınan kadınların \% 45,2' sinin 35 yaş altında, \%41,4'ünün 35-50 yaş aralığında olduğu, $\% 52,2$ 'sinin ilköğretim mezunu, \%96,8'inin sosyal güvencesinin olduğu ve \%74,7'sinin ev hanımı olduğu belirlendi. Kadınlara gelir durumları sorulduğunda büyük çoğunluğundan $(\% 68,3)$ gelirlerinin giderlerine denk olduğu cevabı alınırken, sigara kullanma oran $\% 16,7$ olarak saptand1.
Tablo 1'de kadınların obstetrik ve jinekolojik özelliklerine yönelik bulgulara yer verildi. Kadınların \%63,0'ünün 1-3 arasında gebelik geçirdiği, \%79,6'sının 1-3 arasında doğum yaptığı, \%30,8'inin çeşitli nedenlerle düşük ve/veya küretaj geçirdiği belirlendi. Kadınların ilk adet yaşı 13,4 $\pm 1,5$ (min:9, maks:18) idi. Kadınların ilk gebelik yaşları sorulduğunda \%34,2'sinin ilk gebeliğini 19 yaş ve altında geçirdiği ve \%9,6'sının evde doğum yaptığı saptandı. Araştırma kapsamına alınan kadınların \%37,6'sının aile planlaması yöntemi kullanmadığ1, \%26,9'unun ise etkin olmayan yöntemleri kullandığı belirlendi. Kadınlara daha önceden oral kontraseptif kullanma durumları sorulduğunda \%23,7'sinin çeşitli sürelerde kullandığı saptandı (Tablo 1).

\begin{tabular}{|c|c|c|c|}
\hline Özellikler & . & $\mathbf{N}$ & $\%$ \\
\hline Gebelik sayısı & $\begin{array}{l}\text { Hiç gebelik geçirmemiş } \\
1-3 \\
4 \text { ve üzeri }\end{array}$ & $\begin{array}{l}19 \\
117 \\
50\end{array}$ & $\begin{array}{l}10,2 \\
63,0 \\
26,8\end{array}$ \\
\hline Doğum sayısı & $\begin{array}{l}\text { Hiç doğum yapmamış } \\
1-3 \\
4 \text { ve üzeri }\end{array}$ & $\begin{array}{l}19 \\
148 \\
19\end{array}$ & $\begin{array}{l}10,2 \\
79,6 \\
10,2\end{array}$ \\
\hline Düşük/Küretaj (n:167) & $\begin{array}{l}\text { Var } \\
\text { Yok }\end{array}$ & $\begin{array}{l}37 \\
83\end{array}$ & $\begin{array}{l}30.8 \\
69.2\end{array}$ \\
\hline Evde doğum (n:167) & $\begin{array}{l}\text { Var } \\
\text { Yok }\end{array}$ & $\begin{array}{l}16 \\
151\end{array}$ & $\begin{array}{l}9,6 \\
90,4\end{array}$ \\
\hline İlk gebelik yaşı (n:167) & $\begin{array}{l}19 \text { yaş ve altı } \\
20 \text { yaş ve üzeri }\end{array}$ & $\begin{array}{l}57 \\
110\end{array}$ & $\begin{array}{l}34,2 \\
65,8\end{array}$ \\
\hline $\begin{array}{l}\text { Kullanılan aile planlaması } \\
\text { yöntemi }\end{array}$ & $\begin{array}{l}\text { Kullanmiyor } \\
\text { Kondom } \\
\text { RİA } \\
\text { Oral kontraseptif } \\
\text { Tüp ligasyonu } \\
\text { Geri çekme }\end{array}$ & $\begin{array}{l}70 \\
26 \\
26 \\
5 \\
9 \\
50\end{array}$ & $\begin{array}{l}37,6 \\
14,0 \\
14,0 \\
2,7 \\
4,8 \\
26,9\end{array}$ \\
\hline $\begin{array}{l}\text { Daha önce oral kontraseptif } \\
\text { kullanımı }\end{array}$ & $\begin{array}{l}\text { Var } \\
\text { Yok }\end{array}$ & $\begin{array}{l}44 \\
142\end{array}$ & $\begin{array}{l}23,7 \\
76,3\end{array}$ \\
\hline Toplam & & 186 & 100 \\
\hline
\end{tabular}

RİA: Rahim içi araç 


\begin{tabular}{|c|c|c|c|}
\hline Özellikler & & $\mathbf{N}$ & $\%$ \\
\hline $\begin{array}{l}\text { Ailede rahim ağzı kanser tanısı } \\
\text { alan }\end{array}$ & $\begin{array}{l}\text { Var } \\
\text { Yok }\end{array}$ & $\begin{array}{l}15 \\
171\end{array}$ & $\begin{array}{l}8,1 \\
91,9\end{array}$ \\
\hline $\begin{array}{l}\text { Rahim ağzı kanseri hakkında } \\
\text { bilgi }\end{array}$ & $\begin{array}{l}\text { Var } \\
\text { Yok }\end{array}$ & $\begin{array}{l}91 \\
95\end{array}$ & $\begin{array}{l}48,9 \\
51,1\end{array}$ \\
\hline $\begin{array}{l}\text { Rahim ağzı kanserinden } \\
\text { korunma yollarını bilme }\end{array}$ & $\begin{array}{l}\text { Biliyor } \\
\text { Bilmiyor }\end{array}$ & $\begin{array}{l}81 \\
105\end{array}$ & $\begin{array}{l}43,5 \\
56,5\end{array}$ \\
\hline 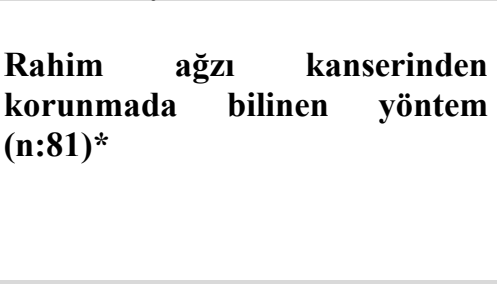 & $\begin{array}{l}\text { HPV aşısı } \\
\text { Düzenli pap-smear testi } \\
\text { Düzenli doktor muayenesi } \\
\text { Az doğum yapmak } \\
\text { Erken yaşta doğum yapmamak } \\
\text { Kanser belirtilerini bilmek } \\
\text { Genital bölgenin temiz tutulması }\end{array}$ & $\begin{array}{l}7 \\
68 \\
52 \\
4 \\
11 \\
24 \\
20\end{array}$ & $\begin{array}{l}3,8 \\
36,6 \\
28,0 \\
2,2 \\
5,9 \\
12,9 \\
10,8\end{array}$ \\
\hline $\begin{array}{l}\text { Rahim ağzı kanserinin } \\
\text { belirtilerini bilme durumu }\end{array}$ & $\begin{array}{l}\text { Biliyor } \\
\text { Bilmiyor }\end{array}$ & $\begin{array}{l}36 \\
150\end{array}$ & $\begin{array}{l}19,3 \\
80,7\end{array}$ \\
\hline $\begin{array}{l}\text { Rahim ăgzı kanserinin bilinen } \\
\text { belirtileri (n:36)* }\end{array}$ & $\begin{array}{l}\text { Su gibi, kanla bulaşık vaginal akıntı } \\
\text { Adetler arasında kanama } \\
\text { Cinsel ilişki sırasında kanama } \\
\text { Bel ve karın ağrısı }\end{array}$ & $\begin{array}{l}16 \\
23 \\
20 \\
8\end{array}$ & $\begin{array}{l}44,4 \\
63,9 \\
55,6 \\
22,2\end{array}$ \\
\hline Toplam & & 186 & 100 \\
\hline
\end{tabular}

*Birden fazla seçenek işaretlenmiştir.

Araştırma kapsamına alınan kadınların \%8,1'inin ailesinde (anne, anneanne, babaanne, teyze, hala) rahim ağzı kanseri tanısı alan bireyler olduğu belirlendi. Kadınların \%48,9'u rahim ağzı kanseri hakkında bilgi sahibi iken, \%56,5'i "Rahim ağz1 kanserinden korunma yolu var midır?" sorusuna "Bilmiyorum" cevabını verdi. Rahim ağz1 kanserinden korunmada en yüksek oranda $(\% 36,6)$ bilinen yöntem düzenli vaginal muayene/pap-smear testi olarak saptand1. Rahim ağzı kanserinin belirtilerini bilenlerin oranı \%19,4 iken en çok bilinen ilk üç belirti sırası ile adetler arasında kanama $(\% 63,9)$, cinsel ilişki sırasında kanama $(\% 55,6)$ ve ince, su gibi, kanla bulaşık vaginal akıntı $(\% 44,4)$ idi (Tablo 2).

Tablo 3. Araştırma grubunun rahim ağzı kanserinden korunma ve HPV aşısı hakkındaki bilgi düzeylerine ilişkin özellikleri

\begin{tabular}{|c|c|c|c|}
\hline Özellikler & & $\mathbf{N}$ & $\%$ \\
\hline $\begin{array}{l}\text { Rahim ağzınızdan sürüntü/örnek } \\
\text { aldırma durumu }\end{array}$ & $\begin{array}{l}\text { Aldiran } \\
\text { Aldirmayan }\end{array}$ & $\begin{array}{l}96 \\
90\end{array}$ & $\begin{array}{l}51,6 \\
48,4\end{array}$ \\
\hline $\begin{array}{l}\text { Rahim ă̆zından örnek aldırma sıklığı } \\
\text { (n:96) }\end{array}$ & $\begin{array}{l}\text { Y1lda bir } \\
3 \text { y1lda bir } \\
5 \text { y1lda bir } \\
\text { Sadece } 1 \mathrm{kez}\end{array}$ & $\begin{array}{l}29 \\
12 \\
10 \\
45\end{array}$ & $\begin{array}{l}30,2 \\
12,5 \\
10,4 \\
46,9\end{array}$ \\
\hline $\begin{array}{l}\text { Human papilloma virüsü } \text { (HPV) } \\
\text { hakkında bilgi }\end{array}$ & $\begin{array}{l}\text { Evet } \\
\text { Hayır }\end{array}$ & $\begin{array}{l}30 \\
156\end{array}$ & $\begin{array}{l}16,1 \\
83,9\end{array}$ \\
\hline $\begin{array}{l}\text { Rahim ağzı kanseri /HPV aşısı hakkında } \\
\text { bilgi }\end{array}$ & $\begin{array}{l}\text { Evet } \\
\text { Hayır }\end{array}$ & $\begin{array}{l}20 \\
166\end{array}$ & $\begin{array}{l}10,8 \\
89,2\end{array}$ \\
\hline $\begin{array}{l}\text { HPV aşısı uygulanması gereken grup } \\
\text { (n:20) }\end{array}$ & $\begin{array}{l}\text { Evli kadınlar } \\
\text { Cinsel aktif herkes } \\
\text { Adölesan/ergen kızlar }\end{array}$ & $\begin{array}{l}7 \\
12 \\
1\end{array}$ & $\begin{array}{l}35,0 \\
60,0 \\
5,0\end{array}$ \\
\hline Kızına HPV aşısı yaptırmayı düşünme & $\begin{array}{l}\text { Evet } \\
\text { Hayir }\end{array}$ & $\begin{array}{l}13 \\
173\end{array}$ & $\begin{array}{l}7,0 \\
93,0\end{array}$ \\
\hline Toplam & & 186 & 100 \\
\hline
\end{tabular}


Araştırmaya dahil edilen kadınların rahim ağzınızdan sürüntü/örnek aldırma durumları incelendiğinde \%51,6'sının örnek aldırdığı, örnek aldırma sıklıkları sorulduğunda \%10,4'ünün 5 yılda bir düzenli olarak örnek aldırdığı, \%46,9'unun ise tüm yaşamı boyunca sadece $1 \mathrm{kez}$ aldırdığ 1 belirlendi. Kadınların \%16,1'i Human papilloma virüsünü (HPV) duyduklarını ifade ettiler. Human papilloma virüsünü (HPV) duyduklarını ifade eden kadınları \%80'i (24 kadın) HPV'nin rahim ağrı kanserine neden olduğunu bilmekteydi. Rahim ağzı kanseri /HPV aşısını duyup duymadıkları sorulduğunda ise aşının çok az oranda $(\% 10,8)$ bilindiği ve cinsel aktif herkese $(\% 60,0)$ aş1 yapılması gerektiği ifade edildi. "Kızınıza HPV aşısı yaptırmayı düşünür müsünüz?" sorusuna ise kadınları tamamına yakını $(\% 93,0)$ "Hayır" cevabı verdi. Bunun nedeni sorulduğunda da aşı hakkındaki bilgi eksikliği sebep gösterildi (Tablo 3 ).

\begin{tabular}{|c|c|c|c|c|c|c|c|c|}
\hline & & \multicolumn{2}{|c|}{ İlköğretim } & \multicolumn{2}{|c|}{ Lise } & \multicolumn{2}{|c|}{ Üniversite } & \multirow[t]{2}{*}{$p$} \\
\hline & & $\mathrm{n}$ & $\%$ & $\mathrm{n}$ & $\%$ & $\mathrm{n}$ & $\%$ & \\
\hline \multirow{2}{*}{$\begin{array}{l}\text { Rahim ağz1 kanseri hakkında } \\
\text { bilginiz var } \mathrm{m} 1 \text { ? }\end{array}$} & Evet & 38 & 36.9 & 24 & 51.1 & 29 & 80.6 & \multirow{2}{*}{0.001 * } \\
\hline & Hayır & 65 & 63.1 & 23 & 48.9 & 7 & 19.4 & \\
\hline \multirow{2}{*}{$\begin{array}{l}\text { Rahim ağzı kanserinden korunma } \\
\text { yolu var mı? }\end{array}$} & Evet & 32 & 31.1 & 23 & 48.9 & 26 & 72.7 & \multirow{2}{*}{0.001 * } \\
\hline & Hayır & 71 & 69.9 & 24 & 51.1 & 10 & 28.8 & \\
\hline \multirow{2}{*}{$\begin{array}{l}\text { Rahim ağz1 kanserine erken tanı } \\
\text { koyan bir test var mı? }\end{array}$} & Evet & 31 & 30.1 & 21 & 44.7 & 24 & 66.7 & \multirow{2}{*}{$0.001 *$} \\
\hline & Hayır & 72 & 69.9 & 26 & 55.3 & 12 & 33.3 & \\
\hline \multirow{2}{*}{$\begin{array}{l}\text { Rahim ağzınızdan hiç sürüntü/örnek } \\
\text { aldırdınız mı? }\end{array}$} & Evet & 62 & 60.2 & 23 & 48.9 & 11 & 30.6 & \multirow{2}{*}{$0.008^{*}$} \\
\hline & Hayır & 41 & 39.8 & 24 & 51.1 & 25 & 69.4 & \\
\hline \multirow{2}{*}{$\begin{array}{l}\text { Human papilloma virüsünü (HPV) } \\
\text { hiç duydunuz mu? }\end{array}$} & Evet & 7 & 6.8 & 11 & 23.4 & 12 & 33.3 & \multirow{2}{*}{0.001 * } \\
\hline & Hayır & 96 & 93.2 & 36 & 76.6 & 24 & 66.7 & \\
\hline
\end{tabular}

*Pearson Ki-kare

Çalışmada üniversite düzeyinde eğitim alan kadınların, ilköğretim ve lise düzeyinde mezun olan kadınlara göre rahim ağzı kanseri, korunma yolları, erken tanı sağlayan testler hakkında istatistiksel açıdan anlamlı düzeyde daha yüksek oranda bilgi sahibi olduğu saptandı (sırasıyla $p=0.001, p=0.001$, $\mathrm{p}=0.001$ ). Tarama için örnek aldırma davranıșlarının ilköğretim düzeyinde eğitim alan kadınlarda, lise ve üniversite düzeyinde eğitim alan kadınlara göre daha yüksek olduğu görüldü ( $\mathrm{p}=0.008$ ). Human papilloma virüsü hakkında ise genel anlamda bilgi düzeyinin düşük olduğu ancak üniversite mezunu olan kadınlarda biraz daha yüksek oranda olduğu görüldü $(\mathrm{p}=0.001)$ (Tablo 4).
Çalışmada 35-50 yaş arası olan kadınların 35 yaş altı ve 50 yaş üstü olan kadınlara göre rahim ağzı kanserinde erken tanı sağlayan testler hakkında daha yüksek oranda bilgi sahibi olduğu görüldü $(p=0.026)$. Kadınların örnek aldırma davranışlarına bakıldığında ise genel olarak 35 yaş üstü kadınlarda oranın istatistiksel olarak anlamlı düzeyde yüksek olduğu görüldü $(p=0.000)$. Katılımcıların büyük çoğunluğunun da HPV hakkında bilgi sahibi olmadikları saptand $1(\mathrm{p}=0.413)$.

Çalışmada kadınların gelir düzeyi, meslek, sosyal güvence, sigara kullanımı gibi özelliklerine göre serviks kanserinden korunma ve HPV'ye ilişkin bilgi düzeyleri karşılaştırıldığında istatistiksel açıdan anlamlı bir farklılık saptanmadı $(\mathrm{p}>0.05)$ (Tablo 5). 


\begin{tabular}{|c|c|c|c|c|c|c|c|c|}
\hline & & \multicolumn{2}{|c|}{35 yaş altı } & \multicolumn{2}{|c|}{$35-50$ yaş aras 1} & \multicolumn{2}{|c|}{50 yaş üstü } & \multirow[t]{2}{*}{$p$} \\
\hline & & $\mathrm{n}$ & $\%$ & $\mathrm{n}$ & $\%$ & $\mathrm{n}$ & $\%$ & \\
\hline \multirow{2}{*}{$\begin{array}{l}\text { Rahim ağzı kanseri } \\
\text { hakkında bilginiz var mı? }\end{array}$} & Evet & 38 & 45.2 & 43 & 55.8 & 10 & 40.0 & \multirow{2}{*}{$0.255^{*}$} \\
\hline & Hayır & 46 & 54.8 & 34 & 44.2 & 15 & 60.0 & \\
\hline \multirow{2}{*}{$\begin{array}{l}\text { Rahim ağzı kanserinden } \\
\text { korunma yolu var } \mathrm{m} ı\end{array}$} & Evet & 42 & 50.0 & 30 & 39.0 & 9 & 36.0 & \multirow[t]{2}{*}{$0.264^{*}$} \\
\hline & Hayır & 42 & 50.0 & 47 & 61.0 & 19 & 64.0 & \\
\hline \multirow{2}{*}{$\begin{array}{l}\text { Rahim ağz1 kanserine } \\
\text { erken tanı koyan bir test } \\
\text { var mı? }\end{array}$} & Evet & 26 & 31.0 & 40 & 51.9 & 10 & 40.0 & \multirow[t]{2}{*}{$0.026 *$} \\
\hline & Hayır & 58 & 69.0 & 37 & 48.1 & 15 & 60.0 & \\
\hline \multirow{2}{*}{$\begin{array}{l}\text { Rahim ağzınızdan hiç } \\
\text { sürüntü/örnek aldırdınız } \\
\text { mı? }\end{array}$} & Evet & 19 & 22.6 & 55 & 71.4 & 22 & 88.0 & \multirow[t]{2}{*}{ 0.000* } \\
\hline & Hayır & 65 & 77.4 & 22 & 28.6 & 3 & 12.0 & \\
\hline \multirow{2}{*}{\begin{tabular}{ll} 
Human & \multicolumn{2}{r}{ papilloma } \\
virüsünü $\quad(H P V)$ & hiç \\
duydunuz mu? &
\end{tabular}} & Evet & 16 & 19.0 & 12 & 15.6 & 2 & 8.0 & \multirow{2}{*}{$0.413 *$} \\
\hline & Hayır & 68 & 81.0 & 65 & 88.4 & 23 & 92.0 & \\
\hline
\end{tabular}

*PearsonKi-kare

\section{TARTIŞMA}

Herhangi bir hastalık hakkındaki toplumun bilgisi, tutumu ve uygulaması, hastalığın önlenmesi ve kontrol stratejileri için önemli bir firsat sunmaktadır. Rahim ağzı kanseri, HPV ve HPV aşısı ile ilgili aynı coğrafi bölgedeki kadınlar arasında bile sosyokültürel özelliklerden kaynaklı farklı bilgi, tutum ve engeller görülebilmektedir. Her ne kadar HPV aşısı ve/veya tarama programları rahim ağzı kanserinin erken tanısına firsat verse de az gelişmiş ülkelerde ve sağlık hizmetlerine yeteri kadar ulaşamayan kadınlarda önemli bir sağlık sorunu olarak görülmektedir. ${ }^{1}$

Çalışmada kadınların yaklaşık yarısının rahim ağzı kanseri hakkında bilgi sahibi olduğu ancak yarısının da kanserden korunma yollarını bilmediği görüldü. Literatürde kadınların servikal kanser hakkındaki bilgi düzeyleri ile ilgili farklı oranlar bildirilmektedir. Ozan ve ark.nın çalışmasında kadınların \%52,4'ünün serviks kanseri hakkındaki bilgi durumunun yetersiz olduğunu belirtmiştir. ${ }^{17}$ Etyopya'da yapılan bir başka çalışmada bu oran \%46,3 olarak verilmiştir. ${ }^{18}$ Kasa ve ark.nın çalışmasında ise kadınların \% 23,1'inin rahim ağzı kanseri hakkında bilgili sahibi olduğu belirtilmiştir. ${ }^{8}$ Çin'de yapılan bir başka çalışmada da kadınların \%45 ile \% 77 gibi değișen oranlarda rahim ağzı kanseri hakkında bilgi sahibi oldukları belirtilmektedir. ${ }^{19,20}$ Ülkelerin gelişmişlik düzeyleri ve kadınların sağlık hizmetlerine ulaşım olanaklarına bağlı olarak hastalık ile ilgili farklı bilgi, tutum ve engeller görülebilmektedir.

Rahim ağz1 kanserinin erken dönemde tanılanması için yüksek riskli lezyonların tespitinde kullanılan Papsmear ve HPV test tabanlı tarama programları önerilmekte ve uygulamaktadır. Kadınların HPV testinin kabul edilebilirliğini etkileyebilecek bilgi ve tutumlarını belirlemek, taramaların farkındalığını artırmak ve yaygınlaştırmak açısından önemlidir. ${ }^{21}$ Araştırmada kadınların \%36,6's1 tarafından rahim ağzından alınan örneğin kanserin erken tanılanmasını sağlayan bir yöntem olduğunu bilinirken, bu amaçla \%51,6'sının örnek aldırdığı, örnek aldırma sıklıkları sorulduğunda sadece \%10,4'ünün 5 y1lda bir düzenli olarak örnek aldırdığı belirlendi. Ülkemizde yapılan bir başka çalışmada ise kadınların \%44,1'inin hiç Papsmear testi yaptırmadığ 1 belirtilmektedir. ${ }^{22}$ Literatür incelendiğinde Aweke ve ark. Etyopya'da yaptığı çalışmada kadınların \% 9,9'u rahim ağzı kanseri için tarama yaptırdığını belirtmektedir. ${ }^{18}$ Kasa ve ark.nın çalışmasında ise bu oran \% 7,3 idi. ${ }^{8}$ Jradi ve ark.nın çalışmasında ise kadınların \% 63,3'ünün rahim ağzı kanseri için herhangi bir tarama yöntemi uygulamadıkları belirtilmektedir. ${ }^{1}$ Araştırma sonuçları ülkelerin gelişmiş̧lik düzeylerine bakılmaksızın kadınların rahim ağzı kanseri hakkında yeteri kadar bilgi sahibi olmadığını göstermektedir.

Rahim ağzı kanseri hakkında bilgi sahibi olunması ve belirtilerin erken dönemde fark edilmesi hastalığın prognozu açısından oldukça önemlidir. Çalışmada rahim ağzı kanserinin belirtilerini bilenlerin oranı \%19,3 idi ve en çok bilinen ilk üç 
belirti sırası ile adetler arasında kanama $(\% 63,9)$, cinsel ilişki sırasında kanama $(\% 55,6)$ ve ince, su gibi, kanla bulaşık vaginal akıntı $(\% 44,4)$ idi. Açıkgöz ve ark.nın çalışmasında serviks kanseri belirtilerini bilmeyenlerin oran1 \%37,5 ile \%52,6 arasında değişmektedir. ${ }^{22}$ Kadınların rahim ağZı kanserinin belirti ve bulguları, risk faktörlerine yönelik farkındalıklarının artması, kanserin erken tanıs1, tedavisi ve önlenmesinde büyük önem taşımaktadır.

Çalışmada kadınların \%16,1'i Human papilloma virüsü (HPV) hakkında bilgi sahibi idi. Human papilloma virüsünü (HPV) duyduklarını ifade eden kadınları \%80'i (24 kadın) HPV'nin rahim ağrı kanserine neden olduğunu bilmekteydi. Ozan ve ark.nın çalışmasında katılımcıların \%33,6'sının HPV'yi bildiği belirtilmektedir. ${ }^{17}$ Bir başka çalışmada ise katılımcıların sadece \%15,9'u HPV infeksiyonunu duyduklarını bildirmektedir. ${ }^{23}$ Literatürde yapılan benzer çalışmalarda da HPV'nin rahim ağzı kanserine neden olan bir ajan olduğu bilgisine farkl 1 oranlarda (\%22,1-35,0) rastlanmaktadır. ${ }^{19,20}$ Benzer çalışmalarda da kadınların HPV'nin rahim ağzı kanserinin nedensel bir faktörü olduğunu bildiklerini bildirilmektedir. ${ }^{24}$

HPV infeksiyonu ve prekanseröz lezyonlara karşı taramalar güvenli ve oldukça etkili bir strateji olmakla birlikte birkaç faktör hastalık riskini artırabilmektedir. ${ }^{25,26}$ Sosyo-ekonomik koşullar, kültürel özellikler, iletişim engelleri, aşının düşük algılanan etkinliği, yan etkiler ve güvenlikle ilgili endişeler aşılanmanın kabul edilebilirliğini etkilemektedir. ${ }^{11}$ Araştırma kapsamına alınan on kadından biri $(\% 10,8)$ HPV aşısını bildiğini ve cinsel aktif herkese $(\% 60,0)$ aşının yapılması gerektiğini ifade etti. Ozan ve ark.nın çalışmasında HPV aşısını bilen kadınların oranı $\% 44,6$ olarak belirtilmektedir. ${ }^{17}$ Literatürde katılımcıların \%13,319,4 oranında HPV aşısının rahim ağzı kanserine karşı koruyuculuğunun bildiğini belirtilmektedir. ${ }^{19,20}$ Dursun ve ark.nın çalışmasında kadınların \%45'i HPV'yi duyduklarını ve \%41'i HPV ile serviks kanserinin ilişkili olduğunu bildiklerini belirtmektedirler. $^{27}$

Aşı sonuçları ile ilgili sınırlı ebeveyn bilgisi, sağlık hizmeti sunucularının öneri eksikliği ve tıbbi bakıma sınırlı erişim dahil olmak üzere, HPV aşılarına karşı sayısız engeller tespit edilmiştir. ${ }^{25}$ Küresel olarak, 2017 itibariyle, 71 ülke kız çocuklarını ve 11 ülke erkek çocuklarını HPV infeksiyonuna karşı aşılamaktadır. ${ }^{28,29} \mathrm{HPV}$ aşısı henüz Türkiye ulusal aşı takviminde yer almamaktadır ve HPV aşı uygulaması tamamen ailenin isteğine bağlı ve ücretlidir. "Kızınıza HPV aşıs1 yaptırmayı düşünür müsünüz?" sorusuna, aş1 hakkındaki bilgi eksikliği sebep gösterilerek kadınları tamamına yakını $(93,0)$ "Hayır" cevabı verdi. Dursun ve ark.nın çalışmasında anneler hem kıları (\%68) hem deerkek çocukları (\%62) için aşıyı kabul edebileceklerini belirtmektedirler. ${ }^{27}$ Koreli-
Amerikalı katılımcılarla yapılan bir başka çalışmada ise, HPV aşılamasına ilişkin olumsuz alg1 bildirmiştir. ${ }^{30} \mathrm{HPV}$ aşısının 9-15 yaş aralığındaki kız çocuklarına altı aylık zaman diliminde $3 \mathrm{doz}$ şeklinde uygulanması tavsiye edilmektedir. ${ }^{12}$ Literatürde 12 ila 26 yaşları arasında en az bir çocuğu olan kadınların \%50,7'si HPV aşısını kendilerine yaptırma konusunda istekli olduklarını belirtirken $^{23}$, servikal kanser tanısı alan kadınlarla yapılan çalışmada katılımcıların \%78,3'ü, önerildiyse aşılacağını belirtmektedir. ${ }^{11}$ Ebeveynlerin HPV ve aşı hakkında bilgi eksikliği, çocukları için aşı yaptırmayı reddetmelerinin yaygın bir nedenidir ve ebeveyn izni, yüksek aşı oranının elde edilmesi için şarttır. ${ }^{30,31}$ Ebeveynlere HPV hakkında yeterli ve doğru bilgi sunulması, aşılanma kararının önemli bir belirleyicisidir. ${ }^{32}$

Çalışma sonuçlarına göre rahim ağzı kanseri, korunma yolları, erken tanı sağlayan testler hakkında bilgi sahibi olan kadınların oranı üniversite düzeyinde eğitim alanlarda daha fazla idi. Tarama için örnek aldırma davranışları ise ilköğretim düzeyinde eğitim alan ve 35 yaş üstü kadınlarda yüksekti. Pınar ve ark.nın çalışmasında kadınların eğitim durumu ile papsmear testini bilme ve yaptırma durumları arasındaki farklar anlamlı bulunurken ${ }^{33}$, Ünalan ve ark.nın çalışmasında da eğitim seviyesi yükseldikçe test hakkında bilgi düzeyinin de arttığı belirtilmektedir. ${ }^{34}$ Alwahaibi ve ark.nın çalışmasında da benzer şekilde eğitim yükseldikçe kadınlarda servikal kanser ve tarama davranışlarının arttığı görülmektedir. ${ }^{35}$ Napolitano ve ark.nın çalışmasında da okuma yazma bilmeyenlere kıyasla 11 yıl veya daha fazla eğitim almış kadınların servikal kanser ve HPV hakkında bilgi sahibi oldukları belirtilmektedir. ${ }^{36}$ Chaka ve ark.nın çalışmasında eğitim seviyesi yükseldikçe kadınların servikal kanseri duyma oranlarının da yükseldiği belirtilmektedir. ${ }^{37}$ Gatumo ve ark.nın çalışmasında da eğitim seviyesi düştükçe kanser ve korunma hakkında bilgi seviyesinin de azaldığ belirtilmektedir. ${ }^{38}$

Türkiye Nüfus ve Sağlık Araştırması (TNSA) 2013 verilerine göre eğitim düzeyi ve ortanca ilk evlenme yaşı arasında pozitif bir ilişki vardır. Lise ve üzeri eğitim almış kadınlar için ortanca ilk evlilik yaşı 24,6 iken, ortaokulu tamamlamış kadınlarda 20,8, eğitimi olmayan veya ilkokulu bitirmemiş kadınlarda ise 18,9'dur. Yaş aralıklarına göre bakıldığında ortanca ilk evlenme yaşı ilkokul mezunu 35-39 yaş arası kadınlarda 18,3, 40-44 yaş arası kadınlarda 18,3, 45-49 yaş arası kadınlarda ise 19,1 'dir. ${ }^{39}$ Türk toplumunda aktif cinsel yaşamın genellikle evlilikle birlikte başlaması obstetrik ya da jinekolojik nedenlerle muayeneye gitme oranlarının artırması ve daha yüksek oranda Papsmear yaptırmaları sonucunu açıklayabilir.

Human papilloma virüsü hakkında ise genel anlamda bilgi düzeyi düşük iken üniversite mezunu olan ve 35 yaş altı kadınlarda oranın daha yüksekti. 
Pınar ve ark.nın çalışmasında kadınların eğitim durumu ile HPV aşısını duymaları arasındaki farkın anlamlı olduğu belirtilmektedir. ${ }^{33}$ Teteh ve arkadaşlarının çalışmasında yaş yükseldikçe HPV ve rahim ağzı kanseri hakkında bilgi düzeyinin

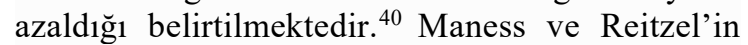
çalışmasında ise 18-39 yaş grubundaki katılımcıların 60 yaş ve üstü gruptaki katılımcılara göre bilgi düzeylerinin daha yüksek olduğu belirtilmektedir. ${ }^{41}$ TNSA 2013 verilerine göre kadınların yaş aralıkları ile eğitim seviyeleri karşılaştırıldı ğında 20-24 yaş arası kadınların \%48,5'inin, 25-29 yaş arası kadınların \%44.4'ünün, 30-34 yaş arası kadınların ise \%34,7'silise ve üzerinde eğitim aldığı görülmektedir. ${ }^{39}$ Eğitim seviyesinin yükselmesi ile bireylerin güvenilir bilgi kaynağına ulaşımı da artmaktadır. $\mathrm{Bu}$ durum üniversite düzeyinde eğitim alan kadınların Human papilloma virüsü hakkında daha yüksek oranda bilgi sahibi olmasının nedeni olarak açıklayabilir. Sonuçlar tarama hizmetlerini kullanımın farkındalığını artırmak ve rahim ağZı kanseri ile ilgili tutumları iyileştirmek için farklı eğitim seviyesi ve yaş grubundaki kadınların eğitim ve danışmanlık gereksinimlerini vurgulamaktadır.

\section{SONUÇ}

Kadınların rahim ağzı kanseri hakkında yeteri kadar bilgiye sahip olmadığı, rahim ağzı kanserinden korunma yollarını ve belirtileri bilmediği, erken tanı ve taramaları konusunda yeterince bilgiye sahip olmadıkları, taramalarını düzenli yaptırmadıkları ve Human papilloma virüsünü (HPV) ve aşısını çok az oranda bildikleri ve aşıya yüksek oranda karşı çıktıkları belirlendi. Kadınların kanserden korunma ve erken tanı yöntemlerine uyum ve HPV aşısı konusunda farkındalığının artması ile davranış değişikliği oluşması için eğitimler planlanmalı ve kadınların yaş ve eğitim durumları göz önünde bulundurulmalıdır. Kadınlara sunulan sağlık hizmetlerinde anahtar rol oynayan ebe ve kadın sağlığı hemşirelerine aşılama ile ilgili yeterli ve doğru bilginin sağlanmasında büyük görev düşmektedir.

\section{KAYNAKLAR}

1. Jradi H, Bawazir A. Knowledge, attitudes, and practices among Saudi women regarding cervical cancer, human papilloma virus (HPV) and corresponding vaccine. Vaccine. 2019;37:530-537.

2. deMartel C, Plummer M, Vignat J, Franceschi $\mathrm{S}$. Worldwide burden of cancer attributable to HPV by site, country and HPV type. Int J Cancer. 2017;141:664-670.

3. Vaccarella S, Laversanne M, Ferlay J, Bray F. Cervical cancer in Africa, Latin America and the Caribbean and Asia: Regional inequalities and changing trends. Int $\mathrm{J}$ Cancer 2017;141:1997-2001.

4. Napolitano F, Gualdieri L, Santagati G, Angelillo I.F. Knowledge and attitudes toward HPV infection and vaccination among immigrants and refugees in Italy.Vaccine. 2018;36:7536-7541.

5. Türkiye Halk Sağlığ Kurumu Türkiye Kanser İstatistikleri, Editörler: Murat Gültekin Güledal Boztaş, Ocak $2014 \quad$ Verileri. http://kanser.gov.tr/Dosya/ca_istatistik/2009ka nseraporu.pdf. Erişim tarihi: $\overline{0} 7.02 .2019$.

6. Anantharaman V V. A cross-sectional study on knowledge, attitude, and practice on cervical cancer and screening among female health care providers of Chennai Corporation. J AcadMedSci. 2013;2(4):124-128.

7. Raychaudhuri S, Mandal S. Current Status of Knowledge, Attitude and Practice (KAP ) and Screening for Cervical Cancer in Countries at Different Levels of Development. Asian Pacific J CancerPrev. 2012;13:4221-4227.

8. Kasa AS, Tesfaye TD, Temesgen WA. Knowledge, attitude and practice towards cervical cancer among women in Finote Selam city administration, West Gojjam Zone, Amhara Region, North West Ethiopia, 2017. Afri Health Sci. 2018;18(3):623-636.

9. Kim KS, Park SA, Ko KN, Yi S, Cho YJ. Current status of human papilloma virus vaccines. ClinExpVaccineRes. 2014;3:168-175.

10. Yüksel B, Şencan H, Kabil Kucur S, Gözükara İ, Seven A, Polat M, ve ark. Human PapillomaVirus (HPV) Enfeksiyonu ve HPV Aşısı Hakkında Bilgi Düzeyi ve Genel Eğilimler; Dumlupınar Üniversitesi - Evliya Çelebi Eğitim Ve Araştırma Hastanesi'ndeki Doktor, Hemşire ve Sağlık Personellerini İçeren Anket Taraması Jinokoloji - Obstetrik ve Neonatoloji Tıp Dergisi. 2015;12(2):64 - 67.

11. Edler M, Fernandez A, Anderson K, Pierce JY, Scalici J, Daniel CL. HPV vaccination, knowledge, andattitudes among young cervical cancer survivors in the Deep South. Vaccine. 2019;37:550-557.

12. Harper DM, DeMars LR. HPV vaccines-A review of the first decade Gynecologic Oncology. 2017;146:196-204.

13. WHO | Comprehensive cervical cancer prevention and control - a healthier future for girls and women. WHO n.d. http://www.who.int/reproductivehealth/publica tions/cancers/9789241505147/en/ (accessedNovember 7, 2017).

14. Göl I, Erkin Ö. Knowledge and practices of nurses on cervical cancer, HPV and HPV vaccine in Cankiri state hospital, Turkey.J Pak Med Assoc. 2016;66(12):1621-1626.

15. Saglik TC. Bakanlığı Türkiye Halk Sağlığı Kurumu Kanserle Savaş Dairesi Başkanlığı. 
Serviks Kanseri Taramasi Ulusal Standartları (National Standards of Cervical Cancer Screening) (InTurkish). [Online] [Cited 2015 Nov 2]. Available from: URL:

16. https://hsgm.saglik.gov.tr/tr/kanser-taramastandartlari/listesi/483-serviks-kanseri-taramaprogram $\% \mathrm{C} 4 \% \mathrm{~B} 1$-ulusalstandartlar\%C4\%B1.html. Erişim tarihi: 26.03.2019

17. Huh WK, Joura EA, Giuliano AR, Iversen OE, de Andrade RP, Ault KA, et al. Final efficacy, immunogenicity, and safety analyses of a ninevalent human papilloma virus vaccine in women aged 16-26 years: a randomised, doubleblindtrial. Lancet 2017; 390: 2143-2159.

18. Ozan H, Çetinkaya $D$, Atik $Y$, Gümüş E, Özerkan K. Kadın Hastalıkları ve Doğum Polikliniğine Başvuran Hastaların Human Papilloma Virüs ve Hpv Aşısı Hakkındaki Bilgi Düzeylerinin Belirlenmesi. Uludağ Üniversitesi T1p Fakültesi Dergisi 2011;37(3):145-148.

19. Aweke YH, Ayanto SY, Ersado TL. Knowledge, attitude and practice for cervical cancer prevention and control among women of child bearing age in HossanaTown, Hadiyazone, SouthernEthiopia: Communitybasedcross- sectional study. PLoS ONE. 2017;12(7): e0181415. https://doi.org/10.1371/journal.pone.0181415

20. Baloch Z, Yasmeen N, Li Y, Zhang W, Lu H, $\mathrm{Wu} \mathrm{X}$, et al. Knowledge and Awareness of Cervical Cancer, Human Papilloma virus (HPV), and HPV Vaccine Among HPVInfected Chinese Women. MedSciMonit2017;23:4269-4277.

21. Feng $\mathrm{S}, \mathrm{Xu} \mathrm{X}$, Jin $\mathrm{Y}$, Yao $\mathrm{X}$. Women'sknowledge of humanpapillomavirus (HPV) and their attitudes toward HPV vaccine: preparingfor HPV vaccination in China. AsiaPac J Public Health 2012;24(3):522-531. https://doi.org/10.1177/1010539511415838.

22. Tatar O, Thompson E, Naz A, Perez S, Shapiroa GK, Wade K, et al. Factors associated with human papilloma virus (HPV) test acceptability in primary screening for cervical cancer: A mixed methods research synthesis. PreventiveMedicine. 2018;116:40-50. https://doi.org/10.1016/j.ypmed.2018.08.034

23. Açıkgöz A, Çehreli R, Ellidokuz H. Kadınların Kanser Konusunda Bilgi ve Tutumları ile Erken Tanı Yöntemlerine Yönelik Davranışları. DEÜ Tıp Fakültesi Dergisi. 2011; 25(3):145-154. DOI: $10.5505 /$ deutip.2011.87597

24. Napolitano F, Gualdieri L, Santagati G, Angelillo IF. Knowledge andattitudestoward HPV infectionandvaccinationamongimmigrantsandr efugees in Italy. Vaccine. 2018;36: 75367754.1https://doi.org/10.1016/j.vaccine.2018.1 0.050
25. Waller J, Jackowska M, Marlow L, Wardle J. Exploring age differences in reasons for nonattendance for cervical screening: a qualitative study. BJOG. 2012;119(1):26-32. https://doi.org/10.1111/j.14710528.2011.03030.x.

26. Holman DM, Benard V, Roland KB, Watson M, Liddon N, Stokley S. Barriers to human papilloma virus vaccination among US adolescents. JAMA Pediatrics. 2014;168(1):76. https://doi.org/10.1001/jamapediatrics.2013.27 52.

27. Ashing KT, Carrington A, Ragin C, Roach V. Examining HPV- and HPV vaccine related cognitions and acceptability among US-born and immigrant Hispanics and US-born and immigrantnon-Hispanic blacks: a preliminary catchmentarea study. Cancer Causes Control 2017;28:1341-1347.

28. Dursun P, Kuşçu E, Zeyneloğlu H B, Yanık F B, Ayhan A. 10-15 Yaş Arası Adölesan Çocuğu Olan Annelerin HPV Aşısı Hakkındaki Bilgi ve Tutumları. Türk Jinekoloji ve Obstetrik Derneği Dergisi (TJOD Derg). 2009;6(3):206-210.

29. SAGE guidance for the development of evidence-based recommendations. vaccine-related http://www.who.int/immunization/sage/ Guidelines_development_recommendations.pd f, accessedFebruary 2018. n.d.

30. Baldovin T, Bertoncello C, Cocchio S (CA, Fonzo M, Gazzani D, Buja A, et al. Perception and knowledge of HPV-related and vaccinerelated conditions among a large cohort of university students in Italy. Human Vaccines\&Immunotherapeutics, 2019;28:1 9.doi:10.1080/21645515.2018.1564432

31. Lee Y-M, Riesche L, Lee H, Shim K. Parental HPV knowledge and perceptions of HPV vaccines among Korean American parents. Applied Nursing Research.2018;44:54-59. https://doi.org/10.1016/j.apnr.2018.09.008

32. Marlow L, Forster A, Wardle J, Waller J. Mothers' and adolescents' beliefs about risk compensation following HPV vaccination. Journal of Adolescent Health, 2009;44(5):446451.

33. Madhivanan P, Li T, Srinivas V, Marlow L, Mukherjee S, Krupp K. Human papilloma virus vaccine acceptability among parents of adolescent girls: obstacles and challenges in Mysore, India. PrevMed, 2014;64:69-74.

34. Pınar G, Topuz Ş, An Ş, Doğan N, Kaya N , Algıer L . Başkent Üniversitesi Ankara Hastanesi kadın hastalıkları ve doğum polikliniğine başvuran kadınların HPV aşısı ve serviks kanseri ile ilgili bilgi düzeyleri. Türk Jinekolojik Onkoloji Dergisi, 2010;13(1),:1118. 
35. Ünalan P, Baş G, Atalay A, Kasapbaş T, Uzuner A. Marmara Üniversitesi Kadın Doğum Polikliniğine başvuranların papsmear konusundaki bilgileri ve test sonuçları. Zeynep Kamil Tıp Bülteni, 2005;36(4): 147 - 151.

36. Alwahaibi N, Alsalami W, Alramadhani N, Alzaabi A. Factors Influencing Knowledge and Practice Regarding Cervical Cancer and Papsmear Testing among Omani Women, AsianPac J Cancer Prev,2018; 19(12):3367-3374.

37. Napolitano F, Gualdieri L, Santagati G, Angelillo IF. Knowledge and attitudes toward HPV infection and vaccination among immigrants and refugees in Italy.Vaccine, 2018; 36(49):7536-7541.

doi: 10.1016/j.vaccine.2018.10.050. Epub 2018 Oct 24.

38. Chaka B, Sayed AR, Goeieman B, Rayne S.A survey of knowledge and attitudes relating to cervical and breast cancer among women in Ethiopia. BMC Public Health, 2018; 18(1):1072. doi: 10.1186/s12889-018-5958-8.

39. Gatumo M, Gacheri S, Sayed AR, ScheibeA.Women's knowledge and attitudes related to cervical cancer and cervical cancer screening in Isiolo and Tharaka Nithicounties, Kenya: a cross-sectional study. BMC Cancer, 2018;18(1):745. doi: 10.1186/s12885-018-4642-9.

40. Türkiye Nüfus ve Sağlık Araştırması (TNSA2013). Hacettepe Üniversitesi Nüfus Etütleri Enstitüsü, Ankara 2014. Erişim tarihi: 15.06.2019

Erișim:http://www.hips.hacettepe.edu.tr/tnsa20 13/rapor/TNSA 2013 ana rapor.pdf

41. Teteh DK, Dawkins-Moultin L, Robinson C, LaGroon V, Hooker S, Alexander K, Kittle RA. Use of community forums to increase knowledge of HPV and cervical cancer in African American communities. Journal of Community HealthJune 2019;44(3):492-499.

42. Maness SB, Reitzel LR, Watkins KL, McNeill LH. HPV awareness, knowledge and vaccination attitudes among churchgoingAfrican-American women. American Journal of Health Behavior, 2016;40(6):771778 . 